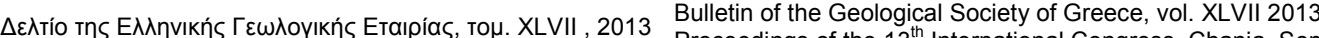

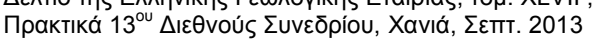

\title{
PALEOBATHYMETRY OF A PLIOCENE VOUTES COAST (HERAKLION, CRETE)
}

\author{
Agiadi K. ${ }^{1}$, Koskeridou E. ${ }^{1}$, Triantaphyllou M. ${ }^{1}$ and Karakitsios V. ${ }^{1}$ \\ ${ }^{1}$ National and Kapodistrian University of Athens, Faculty of Geology and Geoenvironment, \\ Department of Hist.Geology-Paleontology,kagiadi@geol.uoa.gr,ekosker@geol.uoa.gr, \\ mtriant@geol.uoa.gr,vkarak@geol.uoa.gr
}

\begin{abstract}
The fish otolith assemblages identified in the Zanclean sediments of Voutes section (Heraklion, Crete) are analyzed in order to estimate the depth of deposition. The assemblages indicate that Voutes area was in fact a coast inhabited by a neritic fish fauna with significant mesopelagic component, mostly Myctophids. The benthic and benthopelagic group exhibits great diversity. In the late Zanclean, the study area corresponds to a deep neritic environment, which gradually uplifts. At the end of the Zanclean, Voutes area becomes a very shallow coast, as shown by the increased contribution to the assemblage by members of the Gobiid family, as well as the notable presence of Bothidae. Thereafter, the area deepens again, as the shallow benthic-benthopelagic component significantly decreases. This is consistent with the appearance of Pteropods and reaches a peak during the deposition of diatomites at maximum depth. At the upper part of the section, the sea bottom depth decreases again to allow for the deposition of marls with various molluscs remains, where Gadids and Gobiids again reappear. Finally, the upper diatomitic horizon is characterized by a rather poor fish fauna. These observations allow reconstructing the evolution of Voutes coastal area during the latest Zanclean until the Piacenzian.
\end{abstract}

Key words: Fish, otoliths, Zanclean, Teleosts, Mediterranean.

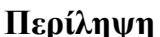

$\Sigma \tau \eta v \quad \pi \alpha \rho o v ́ \sigma \alpha \quad \varepsilon \rho \gamma \alpha \sigma i \alpha \quad \pi \alpha \rho o v \sigma i \alpha ́ \zeta \varepsilon \tau \alpha l \quad \eta \quad \pi \alpha \lambda \alpha \iota \beta \beta \alpha \theta v \mu \varepsilon \tau \rho \imath \kappa \eta \dot{~} \alpha v \dot{\alpha} \lambda v \sigma \eta \quad \tau \omega v$

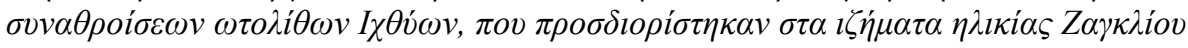

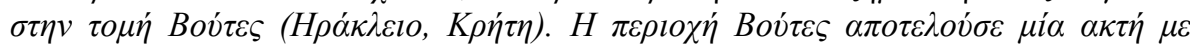

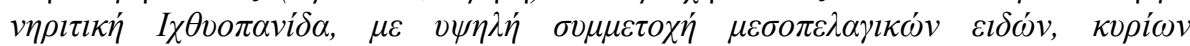

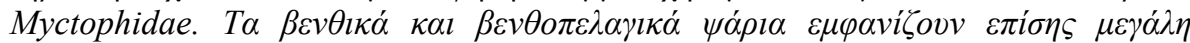

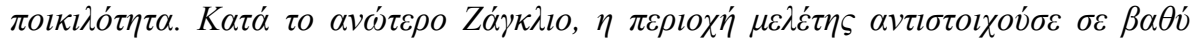

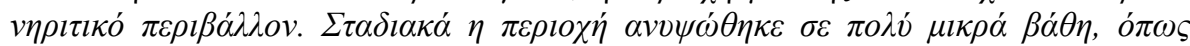

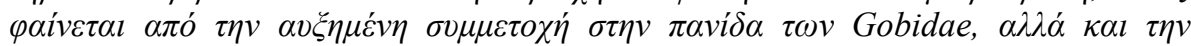

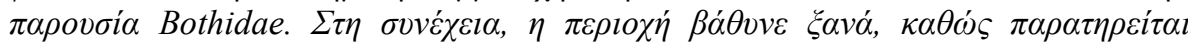

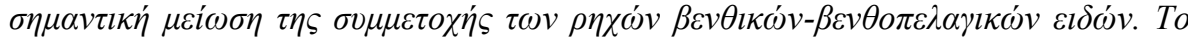

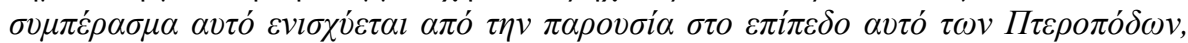

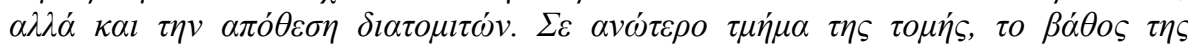

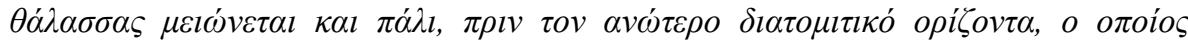

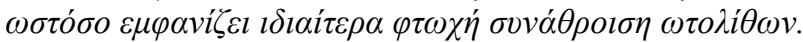

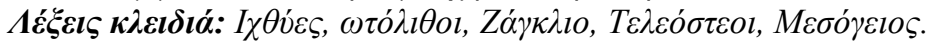

XLVII, No $1-52$ 


\section{Introduction}

Crete Island was created during the Late Miocene through the N-S and E-W extensional deformation of the south Aegean, resulting in the formation of multiple tectonic blocks and Late Miocene to Pleistocene sedimentary basins (Meulenkamp et al., 1988; van Hinsbergen and Meulenkamp, 2006). The Neogene sediments overlie a pile of alpine nappe substratum, which includes the metamorphic Plattenkalk and Phyllites - Quarzites Units followed by the Tripolis and Pindos-Ethia, as well as other minor units (Zachariasse et al., 2011).

The present emerged area of the Heraklion basin is a Pliocene graben structure located at the northern part of the central Crete Island, in the southern segment of the Hellenic Arc, between the mountains Psiloritis and Dicti. The alpine basement formations contain a rich melange of Triassic to Eocene sedimentary and metamorphic rocks, overlain by Neogene and Quaternary sedimentary deposits, recording a great diversity of environments and ecosystems (Symeonidis and Konstantinidis, 1967). The Pliocene Heraklion basin occurred in a region marked by a great number of successive paleogeographic Miocene frameworks, in the vicinity of the Messara basin. In the late Late Tortonian the activation of the eastern - western oriented Agia Varvara fault differentiated the two realms, which evolved separately since then (Delrieu et al., 1991).

The Pliocene deposits of the Heraklion basin are the most extensive on the Island. The marine sediments of the lowermost Pliocene generally overlie the late Messinian deposits (Delrieu et al., 1991; Meulenkamp et al., 1979), and consist of whitish marls and marly limestones of deep water origin, reflecting the Pliocene flooding which followed the lago-mare episode immediately after the Mediterranean Salinity Crisis.

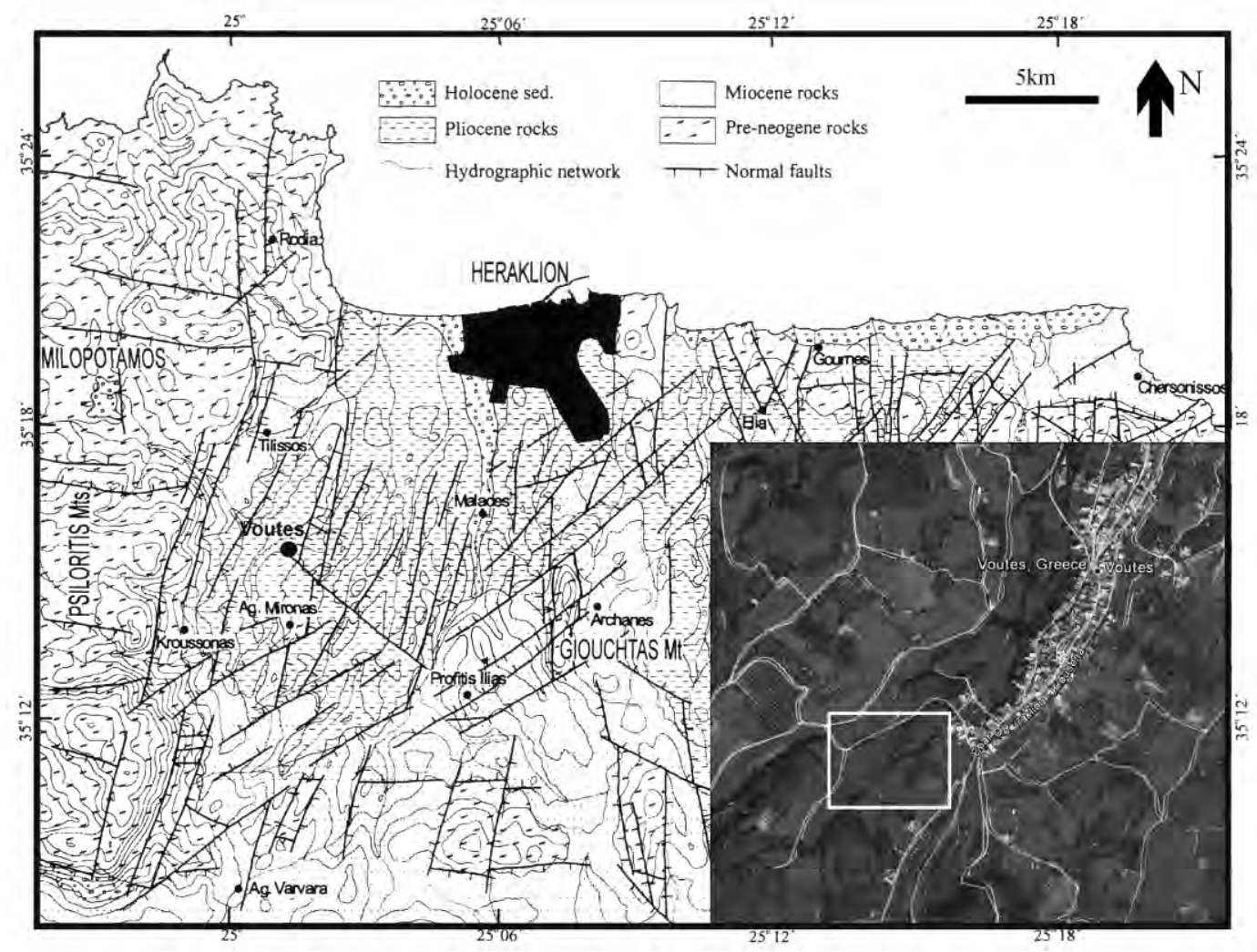

Figure 1 - Heraklion area geological map (Fassoulas, 2001), indicating Voutes village. 
Fish otoliths provide a unique tool in the investigation of the fish teleostean paleofaunas, due to their taxon - specific morphology, high frequency with which they are found in sediments of varying environments, and their generally good preservation (Nolf, 1985). In addition, they constitute very valuable paleoecological and paleobathymetrical indicators (Nolf and Brzhobohaty, 1994; Girone, 2000; Agiadi et al., 2010; et al., 2011). In the present study, fish otoliths from the Pliocene sediments of Voutes (Heraklion, Crete) are used as indicators in order to reconstruct the depositional depth.

\section{Material and Methodology}

The studied Voutes section is located southwest of the village Voutes in central Crete, south of Heraklion city. Geologically it is situated in the western section of the Heraklion basin (Figure 1). The section's sediments may be placed within the Finikia lithostratigaphic group (of Benda et al., 1974 and Meulenkamp et al., 1979) and include more than 60 meters of marls and sandy marls. Strong gravity flows have formed a series of sand lenses, on the lower part of the section, with distinctive sedimentologic attributes and characteristic fauna. The upper part of the section presents three diatomite horizons. On a total, nine (9) sediment samples were taken along Voutes section. Systematic identifications of the fish otoliths found within these samples are presented in Agiadi et al. (2013).

The relevant chronostratigraphic framework (Agiadi et al., 2013) for the evaluation of the results was provided through calcareous nannoplankton biostratigraphy, based on the biozonation scheme of Rio et al. (1990) as this has been incorporated in the magnetobiochronologic framework of Lourens et al. (2004) in Gradstein et al. (2004). The studied interval from Voutes section is assigned to the biozone MNN16, in particular above the highest occurrence of R. pseudoumbilicus and Sphenolithus spp. following the MNN14/15-MNN16 boundary (3.84 Ma, Lourens et al., 2004; Raffi et al., 2006) and just below the top of D. pentaradiatus paracme (3.61 Ma, Lourens et al., 2004), within the latest Zanclean.

The depth of deposition, through the analysis of the fish otolith assemblage, was estimated using the method of Nolf and Brzobohaty (1994) for bathyal and deep neritic assemblages with a significant mesopelagic component, as it was re-adjusted by Agiadi et al. (2010). According to this methodology, based on the modern depth ranges of all the taxa in each sample (Table 1), the number of possible presences for each 50-meter depth interval is calculated and expressed as a percentage of the total number of taxa involved in the analysis. The depth of deposition for each sediment sample is estimated as the maximum percentage in these plots.

The only requirement for the application of this method is that the systematic position of the fossil taxa has a close affinity to their modern analogues. The presence/absence data used includes only those taxa for which present-day bathymetric information is available. This means that higher order identified otolith specimens were completely excluded from analysis. Out of the 43 taxa present in Voutes sediments, only eight are extinct today, Diaphus cavallonis, Myctophum fitchi, Scopelopsis pliocenicus, Pseudophichthys escavaratierensis, Rhynchoconger pantanelli, Parascombrops mutinensis, Gadiculus labiatus and Arnoglossus kokeni. The present-day distributions assigned to these species were those of their most close living relative. To this end, genus level affinity was used, in conjunction with the corresponding present record in the Aegean Sea. These analogies are presented in Table 1. In particular, Scopelopsis pliocenicus has only one living species with a genus-level affinity, Scopelopsis multipunctatus (Hulley, 1990), to which it was assigned. At present, P. splendens is the only Pseudophichthys species occupying the Mediterranean Sea (Bañon et al., 2011). Consequently, P. escavaratierensis was also assigned to P. splendens. Rhynchoconger currently includes seven species, occupying either the Indo-Pacific or the western Atlantic coasts at various depths (Whitehead et al., 1986). In addition, congrids in the present Mediterranean include three species Ariosoma balearicum, Conger conger and Gnathophis mystax (Whitehead et al., 1986).

$\underline{\text { XLVII. No } 1-54}$ 
Table 1 - Present-day bathymetric distribution of the fish taxa identified in Voutes outcrop sediments or their modern equivalent. The data has been acquired from FishBase (Froese and Pauly, 2012).

\begin{tabular}{|c|c|c|c|}
\hline \multicolumn{2}{|c|}{\begin{tabular}{|l|} 
Taxonomic placement \\
\end{tabular}} & \multirow{2}{*}{$\begin{array}{l}\text { Bathyme tric } \\
\text { range }(\mathrm{m})\end{array}$} & \multirow[b]{2}{*}{ References } \\
\hline Family & Genus/Species & & \\
\hline \multicolumn{4}{|l|}{ PELAGIC TAXA } \\
\hline Sternoptychidae & Maurolicus muelleri & $50->1524$ & Okiyama 1971 \\
\hline Phosichthyidae & Vinciguerria poweriae & $50-1000$ & Yang et al 1996 \\
\hline \multirow[t]{13}{*}{ Myctophidae } & Ceratoscopelus maderensis & $51-1082$ & Mytilineou et al 2005 \\
\hline & Diaphus adenomus & $180-600$ & Hulley 1990 \\
\hline & Diaphus holti & $40-777$ & Mytilineou et al 2005 \\
\hline & $\begin{array}{l}\text { Diaphus metopoclampus (equiv. } \\
\text { D.cavallonis) }\end{array}$ & $90-1085$ & Mytilineou et al 2005 \\
\hline & Diaphus rafinesquii & $40-1200$ & Bogutskaya 2007 \\
\hline & Diaphus splendidus & $40-750$ & Hulley 1990 \\
\hline & Diaphus taaningi & $40-475$ & Hulley 1990 \\
\hline & Hygophum benoiti & $51-700$ & Hulley 1990 \\
\hline & Hygophum hygomii & $0-800$ & Hulley 1990 \\
\hline & Myctophum punctatum (equiv. M.fitchi) & $0-1000$ & Muus and Nielsen 1999 \\
\hline & Lobianchia dofleini & $20-750$ & Hulley 1990 \\
\hline & Notoscopelus resplendens & $0-2000$ & Hulley 1990 \\
\hline & $\begin{array}{l}\text { Scopelopsis multipunctatus (equiv. } \\
\text { S.pliocenicus ) }\end{array}$ & $3-2000$ & Hulley 1990 \\
\hline Bregmacerotidae & Bregmaceros spp. & $?-1260 \mathrm{~m}$ & Castellanos-Galindo et al 2006 \\
\hline \multicolumn{4}{|c|}{ BENTHIC AND BENTHOPELAGIC TAXA } \\
\hline \multirow[t]{2}{*}{ Congridae } & $\begin{array}{l}\text { Pseudophichthys splendens (equiv. } \\
\text { P.escavaratierensis) }\end{array}$ & $37-1647$ & Bañon et al 2011 \\
\hline & $\begin{array}{l}\text { Modern Mediterranean Congrids (equiv. } \\
\text { R.pantanelli) }\end{array}$ & $0-700$ & Whitehead et al 1986 \\
\hline Chlorophthalmidae & Chlorophthalmus agassizi & $50-1000$ & Whitehead et al 1986 \\
\hline Moridae & Laemonema spp. & $200-1200$ & Whitehead et al 1986 \\
\hline Gadidae & Gadiculus argenteus (equiv. G. labiatus) & $100-1000$ & Muus and Nielsen 1999 \\
\hline Bythitidae & Grammonus ater & reef-associated & Whitehead et al 1986 \\
\hline Carapidae & Echiodon dentatus & $120-3250$ & OBIS 2006 \\
\hline Atherinidae & Atherina boyeri & $\begin{array}{l}\text { coastal, very } \\
\text { euryhaline }\end{array}$ & Maugé 1990 \\
\hline Apogonidae & Apogon spp. & reef-ass ociated & Whitehead et al 1986 \\
\hline Epigonidae & Epigonus denticulatus (equiv. Epigonus sp.) & $300-600$ & Whitehead et al 1986 \\
\hline Acropomatidae & Synagrops spinosus (equiv. P.mutinensis) & $87-544$ & Mochiuzuki and Gultneh 1989 \\
\hline \multirow[t]{2}{*}{ Sparidae } & Oblada melanura & $?-30$ & Bauchot and Hureau 1990 \\
\hline & Pagellus erythrinus (equiv. Pagellus sp.) & $20-200$ & Bauchot and Hureau 1990 \\
\hline Cepolidae & Cepola macrophthalma & $15-400$ & Whitehead et al 1986 \\
\hline \multirow[t]{7}{*}{ Gobiidae } & Aphia minuta & $0-97$ & Iglesias and Morales-Nin 2001 \\
\hline & Deltentosteus quadrimaculatus & $?-333$ & Mytilineou et al 2005 \\
\hline & Gobius niger & $1-75$ & Whitehead et al 1986 \\
\hline & Gobius paganellus & $?-15$ & Azevedo and Simas 2000 \\
\hline & Lesueurigobius friesii & $10-130$ & Miller 1990 \\
\hline & Lesueurigobius sanzi & $47-117$ & Miller 1990 \\
\hline & $\begin{array}{l}\text { Lesueurigobius suerii (equiv. } \\
\text { Lesueurigobius sp.) }\end{array}$ & $?-337$ & Mytilineou et al 2005 \\
\hline Citharidae & Citharus linguatula & $?-200$ & Nielsen 1981 \\
\hline Bothidae & Arnoglossus spp. & $15-300$ & Whitehead et al 1986 \\
\hline
\end{tabular}

$\underline{\text { XLVII, No } 1-55}$ 
All three species exhibit great depth distribution, from a few tens to more than 700 meters, which was thus used as a generalized assessment of the depth distribution of $\mathrm{R}$. pantanelli. There is no living species placed within the genus Parascombrops, nor is there an Acropomatidae representative occupying the Mediterranean Sea at present. From the comparative morphological similarities between the North Atlantic species Synagrops spinosus (Campana, 2004) and the P. mutinensis otoliths of this and previous studies (Agiadi et al., 2011; Agiadi et al., 2013), it may be considered that this is an appropriate modern analogue to the fossil species. The only Gadiculus Mediterranean inhabitant today is G. argenteus (Muus and Nielsen, 1999), which was accepted here as the modern equivalent of G. labiatus. Finally, Arnoglossus spp. depth values encompass the distribution of all six extant Arnoglossus Mediterranean species (Whitehead et al., 1986).

An initial inspection of the depth distribution of the identified taxa in the samples indicated that the paleodepths did not surpass 1000 meters. Consequently, the analyses were conducted until that depth. In addition, Maurolicus muelleri, Vinciguerria poweriae, Ceratoscopelus maderensis, Diaphus metopoclampus, Diaphus rafinesquii, Myctophum punctatum, Notoscopelus resplendens, Bregmaceros sp., Gadiculus argenteus, Scopelopsis multipunctatus and Pseudophthichthys splendens were excluded from the analyses because their modern depth distribution range is great and encompasses almost entirely the 0-1000 meter interval. Their presence were considered only to clarify ambivalent depth estimates.

\section{Paleobathymetric Analysis}

The paleodepth analysis and estimates are presented in Figures 2 and 3. In sample Voutes b, only three species may be considered, which provided a paleobathymetric estimate between 10-130 meters, Cepola macrophthalma, Deltentosteus aff. quadrimaculatus and Lesueurigobius friesii. In Voutes 3 the analysis delivered an estimate of 50-350 meters. However, this range is affected by the 50-meter intervals used in the analysis. After closer examination, it may be observed that the actual paleodepth estimate ought to be that where both Aphia minuta and Diaphus adenomus could coexist, and that is between 87-100 meters depth. The presence of D. holti, H. hygomii and Laemonema sp. in Voutes 4 leads to a paleodepth estimate between 200-800 meters, with no greater accuracy available for this level. The fish taxa identified in sample Voutes 1 did not allow for any paleobathymetric estimation. In particular, in this sample the following taxa have been identified (Agiadi et al., 2013): Myctophidae indeterminable (ind.), Bregmaceros sp., Laemonema sp., Gadiculus labiatus, Sparidae ind. and Perciformes ind. The great abundance of Bregmaceros sp., in conjunction with the presence of Myctophids and deep-water benthopelagic taxa such as Laemonema sp., Gadiculus labiatus and Perciformes, may indicate a rather deep marine environment, generally exceeding 200 meters.

A mixed fauna is revealed through the paleobathymetric analysis in sample Voutes c. Initially, the graphical results provide an estimate between 300-337 meters, delimited by the maximum depth distribution of $L$. suerii. However, the presence of Oblada melanura is problematic. This benthopelagic fish today inhabits rocky bottom of depths up to 30 meters, in the coasts of the eastern Atlantic and the Mediterranean Sea (Bauchot and Hureau, 1990). In addition, reefassociated taxa Grammonus ater and Apogon sp. (Whitehead et al., 1986) also also present in sample Voutes c. Two faunal units may thus be separated in this level, a deeper neritic unit from an environment reaching depths around 300-337 meters, and a shallow unit from depths between 0-30 meters. 


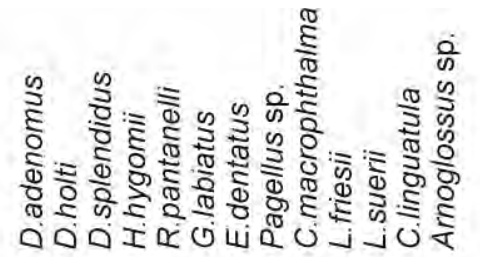

Voutes 6 estimate: $150 \mathrm{~m}$
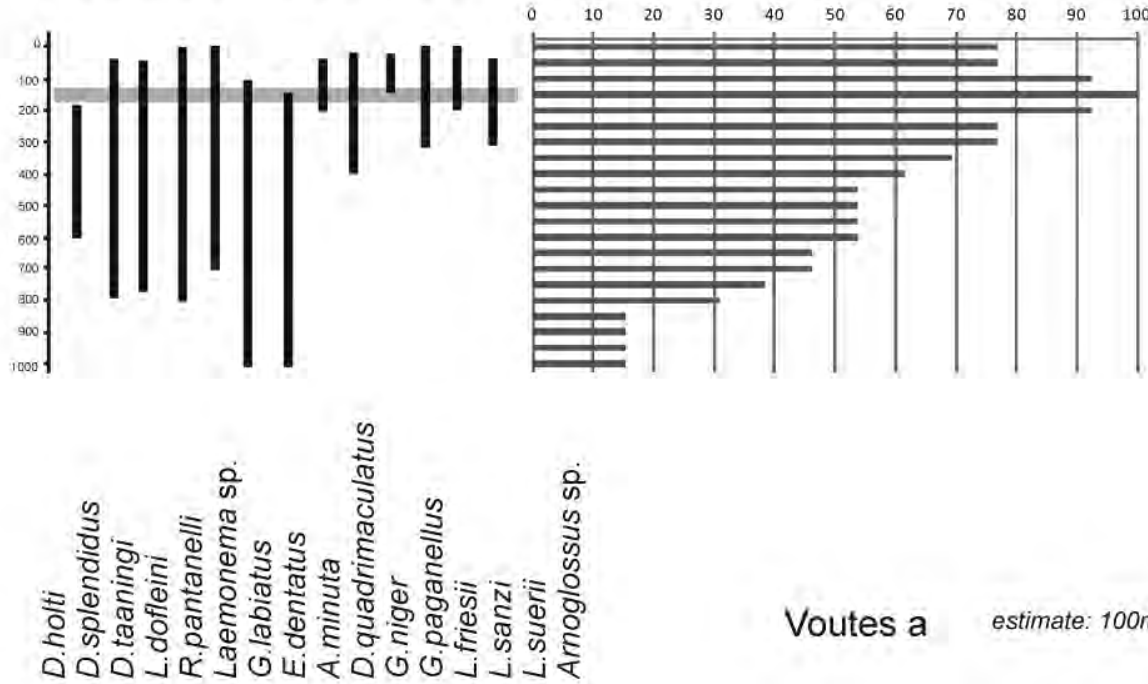

Voutes a estimate: $100 \mathrm{~m}$
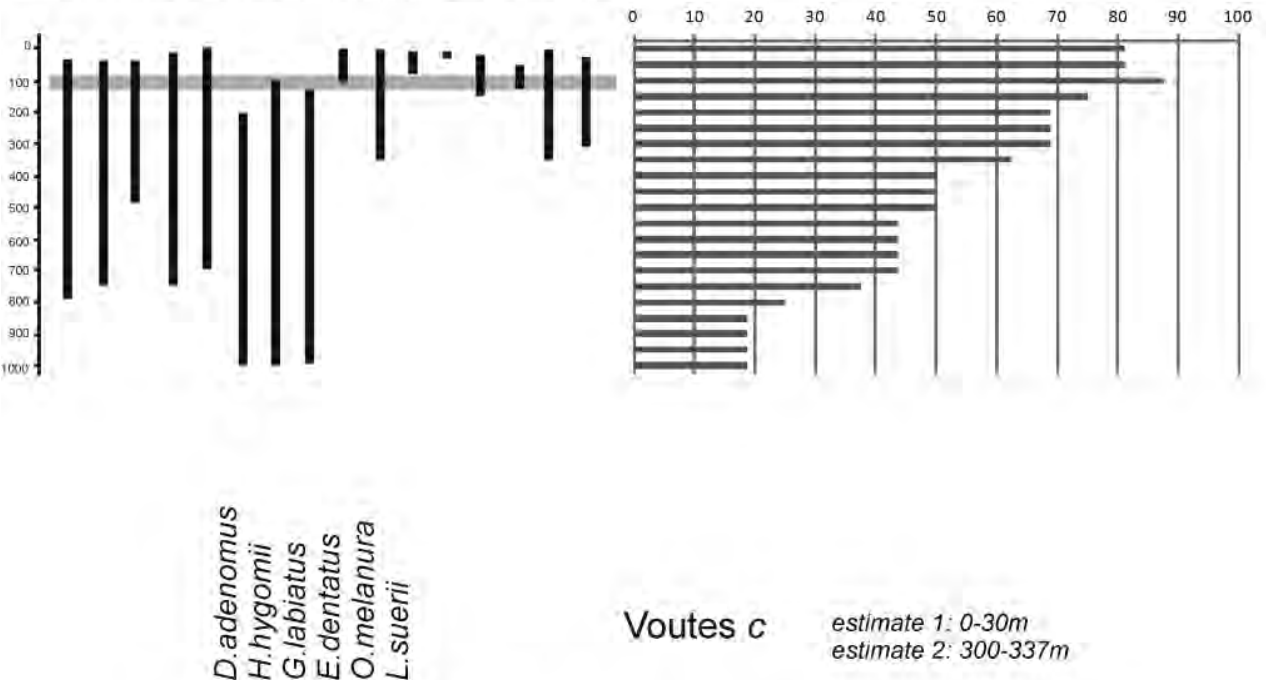

Voutes $c$ estimate 1:0-30m

estimate 2: $300-337 \mathrm{~m}$
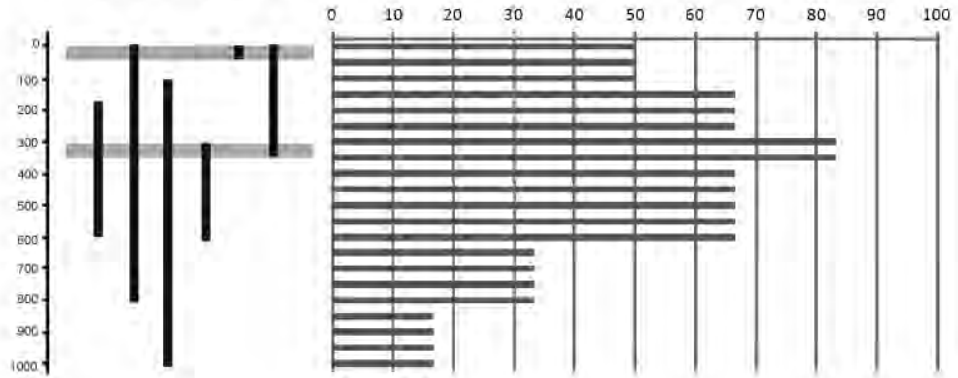

Figure 2 - Paleobathymetric analysis and estimates.

XLVII, No 1 - 57 

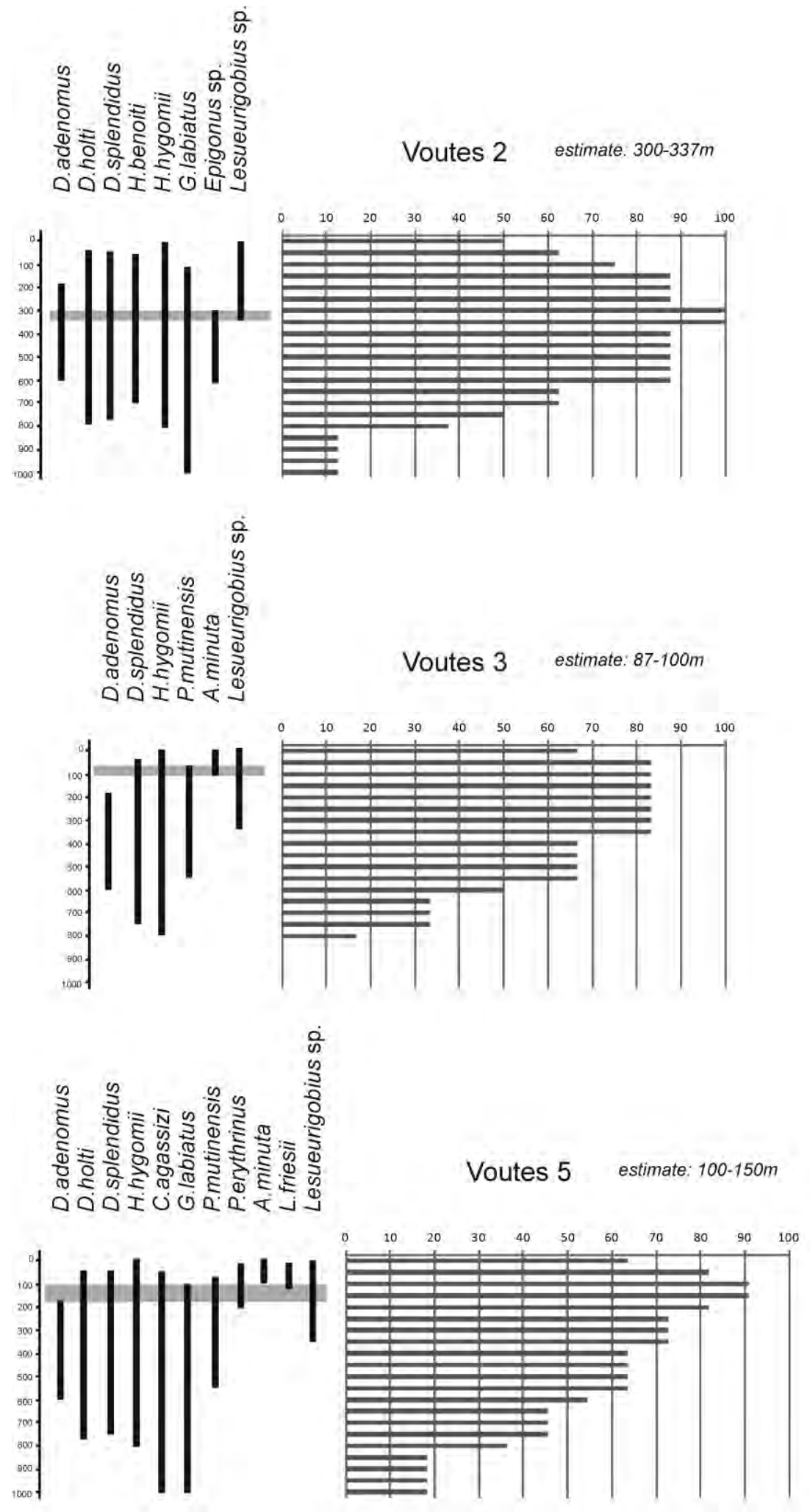

Figure 3 - Paleobathymetric analysis and estimates (continuation).

XLVII. No $1-58$ 


\section{Discussion and Conclusions}

The paleobathymetric curve created from the analysis of the fish otolith fauna uncovered in the Voutes outcrop sediments present an interesting input in the paleogeographic evolution of the Central Crete area, namely the Heraklion basin (Figure 4).

Generally, depths throughout this interval do not exceed 350 meters, although the lower part of the section (Figure 2) exhibits much shallower estimates, up to 150 meters. The deeper environments are found on the upper part of the section (Figure 3). However, no specific trend may be safely concluded from the estimated values. Rather several depth variations are visualized (Figure 4). In addition, the lower part of the Voutes outcrop reveals a mixture of the fish faunas from two realms, a deep water probably autochthonous faunal component, and a shallow allochthonous fauna. This is in accordance with the gravity flows observed at the lower part of the section, which seem to have incurred this mixing. Overall, during the late Zanclean, Voutes area was a coast, habitat for a rich shallow neritic Ichthyofauna. The results presented here offer new input on the tectonic eustatic coupling effect on the paleogeography of central Crete, between 3.84 and 3.61Ma.

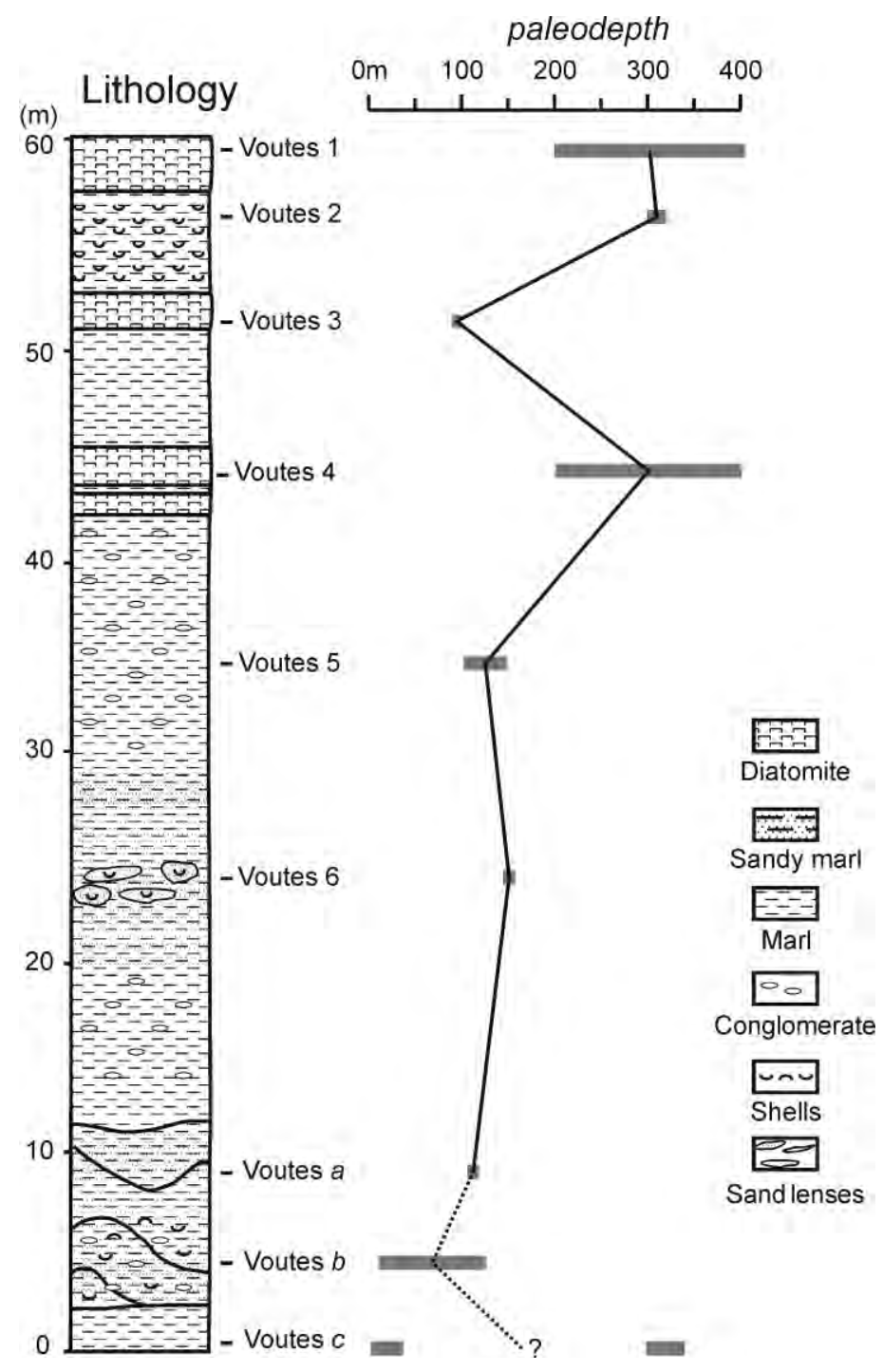

Figure 4 - Voutes section lithology and paleobathymetric curve.

$\underline{\text { XLVII. No } 1 \text { - } 59}$ 


\section{Acknowledgments}

This research has been co-financed by the European Union (European Social Fund - ESF) and Greek national funds through the Operational Program "Education and Lifelong Learning" of the National Strategic Reference Framework (NSRF) - Research Funding Program: Heracleitus II. Investing in knowledge society through the European Social Fund.

\section{References}

Agiadi K., Triantaphyllou M., Girone A., Karakitsios V. and Dermitzakis M. 2010. Paleobathymetric interpretation of the fish otoliths from the lower-middle Quaternary deposits of Kephallonia and Zakynthos Islands (Ionian Sea, western Greece), Rivista Italiana di Paleontologia e Stratigrafia, 116(1), 63-78.

Agiadi K., Triantaphyllou M., Girone A. and Karakitsios V. 2011. The early Quaternary palaeobiogeography of the eastern Ionian deep-sea Teleost fauna: A novel palaeocirculation approach, Palaeogeography Palaeoclimatology Palaeoecology, 306, 228-242.

Agiadi K., Koskeridou E., Triantaphyllou M., Girone A. and Karakitsios V. 2013. Fish otoliths from the Pliocene Heraklion basin (Crete, eastern Mediterranean), Geobios, in press.

Azevedo J.M.N. and Simas A.M.V. 2000. Age and growth, reproduction and diet of sublittoral population of the rock goby Gobius paganellus (Teleostei: Gobiidae), Hydrobiol., 440, 129-135.

Bañon R., Arronte J.C., Serrano A. and Sánchez F. 2011. First records of purple-mouthed conger Pseudophichthys splendens (Anguilliformes: Congridae) from the Galicia Bank (NW Spain). A northward range extension of their distribution in the eastern Atlantic, Cybium, 35(3), 262-264.

Bauchot M.L. and Hureau, J.C. 1990. Sparidae, in Quero, J.C., Hureau, J.C., Karrer, C., Post, A., Saldanha, L., eds., Check-list of the fishes of the eastern tropical Atlantic (CLOFETA), JNICT, Lisbon; SEI, Paris; and UNESCO, Paris. Vol. 2.

Benda L., Meulenkamp J.E. and Zachariasse W.J., 1974. Biostratigraphic correlations in the eastern Mediterranean Neogene. Part I: Correlation between planktonic foraminiferal, uvigerinid, sporomorphal and mammal zonations of the Cretan and Italian Neogene, Newsletter in Stratigraphy, 3, 205-217.

Bogutskaya N.G. 2007. Preliminary assignment of coordinates to type localities in the Catalog of Fishes, Unpublished dbf file.

Campana S.E. 2004. Photographic Atlas of Fish Otoliths of the Northwest Atlantic Ocean, Canadian Special Publications of Fisheries and Aquatic Sciences, 133.

Castellanos-Galindo G.A., Rincon E.A.R., Beltran-Leon B., Zapata L.A. and Baldwin C.C. 2006. Check list of gadiform, ophidiiform and lophiidorm fishes from Colombian waters of the tropical eastern Pacific, Biota Colombiana, 7(2), 191-209, Bogotà.

Delrieu B., Saint-Martin J.P. and Merle D. 1991. Un modele d'evolution tectonosedimentaire dans le domaine Sud-Egeen au Miocene Superieur: L'accident d'Aghia Varvara (Crete Central, Grece), Comptes Rendus de l' Academie des Sciences Paris, 313, 1043-1049.

Fassoulas C. 2001. The tectonic development of a Neogene basin at the leading edge of the active European margin: the Heraklion basin, Crete, Greece, Journal of Geodynamics, 31, 49-70.

Froese R. and Pauly D. eds. 2012, Fish Base, World Wide Web electronic publication. www.fishbase.org, version (12/2012).

Girone A. 2000. The use of fish otoliths for paleobathymetric evaluation of the Lower to Middle Pleistocene deposits in Southern Italy, Bull. Societa Palentologica Italiana, 39(2), 235-242.

Gradstein F., Ogg J. and Smith A. 2004. A Geological Time Scale, Cambridge Univ. Press, 610pp.

Hulley P.A. 1990. Myctophidae, In: Quero, J.C., Hureau, J.C., Karrer, C., Post, A., Saldanha, L., eds., Check-list of the fishes of the eastern tropical Atlantic (CLOFETA), JNICT, Lisbon; SEI; Paris; and UNESCO, Paris, Vol. 1, 398-467. 
Iglesias M. and Morales-Nin B. 2001. Life cycle of the pelagic goby Aphia minuta (Pisces: Gobiidae), Scientia Marina, 65(3), 183-192.

Lourens L., Hilgen F., Shackleton N., Laskar J. and Wilson D. 2004. The Neogene Period. In Gradstein E. et al. (eds.) A Geologic Time Scale 2004, Cambridge Univ. Press, 409-440.

Maugé L.A. 1990. Atherinidae. In Quero, J.C., Hureau, J.C., Karrer, C., Post, A., Saldanha, L., eds., Check-list of the fishes of the eastern tropical Atlantic (CLOFETA), JNICT, Lisbon; SEI, Paris; and UNESCO, Paris. Vol. 2.

Meulenkamp J.E., Dermitzakis M., Georgiadou-Diakeoulia E., Jonkers H.A. and Boerger H. 1979. Field Guide to the Neogene of Crete, Publications of the Geological and Paleontological Department, University of Athens, Athens.

Meulenkamp J.E., Wortel M.J.R., Van Wamel W.A., Spakman W. and Hoogerduyn Strating E. 1988. On the Hellenic subduction zone and the geodynamical evolution of Crete since the late Middle Miocene, Tectonophysics, 146, 203-215.

Miller P.J. 1990. Gobiidae. In Quero, J.C., Hureau, J.C., Karrer, C., Post, A., Saldanha, L., eds., Check-list of the fishes of the eastern tropical Atlantic (CLOFETA), JNICT, Lisbon, SEI, Paris; and UNESCO, Paris. Vol. 2.

Mochiuzuki K. and Gultneh S. 1989. Redescription of Synagrops spinosus (Percichthyidae) with its first record from the West Pacific, Japanese Journal of Ichthyology, 35(4), 421-427.

Muus B.J. and Nielsen J.G. 1999. Sea fish, Scand. Fish. Year Book, Hedehusene, Denmark, 340 p.

Mytilineou C., Politou C.Y., Papaconstantinou C., Kavadas S., D'Onghia G. and Sion L. 2005. Deep-water fish fauna in the Eastern Ionian Sea, Belgian J. Zoology, 135(2), 229-233.

Nielsen J.G. 1981. Citharidae, in Fischer, W., Bianchi, G., Scott, W.B., eds., FAO species identification sheets for fishery purposes, Eastern Central Atlantic; fishing areas 34, 47 (in part). Vol. 2, FAO, Rome.

Nolf D. 1985 Otolithi Piscium, in Schultze, H.P., ed., Handbook of Paleoichthyology, vol. 10, 1145 , Stuttgart.

Nolf D. and Brzobohaty R., 1994. Fish otoliths as paleobathymetric indicators, Paleontologia $i$ evolucio, 24-25, 255-264.

Biogeographic Information System 2006. OBIS-extracted Depth Data. Harvested by E.Agbayani July 2006 at www.iobis.org.

Okiyama M. 1971. Early life history of the gonostomatid fish Maurolicus muelleri (Gmelin), in the Japan Sea, Bull. Japanese Sea Registry of the Fisheries Research Lab, 23, 21-53.

Raffi I., Backman J., Fornaciari E., Palike H., Rio D., Lourens L. and Hilgen F. 2006. A review of calcareous nannofossil astrobiochronology encompassing the past 25 million years, Quaternary Science Reviews, 25(23-24), 3113-3137.

Rio D., Raffi I. and Villa G. 1990. Pliocene-Pleistocene calcareous nannofossil distribution patterns in the western Mediterranean, In Kastens K.A., Mascle J., et al., eds., Proceedings of the ODP, Scientific Results, vol. 107. ODP, College Station TX, 513-533.

Symeonidis N. and Konstadinidis D. 1967. Observations on the Neogenic formations of Central Crete, Annales Géologiques des Pays Helléniques, 19, 657-688.

Van Hinsbergen D.J.J. and Meulenkamp J.E. 2006. Neogene supra-detachment basin development on Crete (Greece) during exhumation of the South Aegean core complex, Basin Research, $18,103-124$.

Whitehead P.J.P., Bauchot M.L., Hureau J.C., Nielsen J. and Tortonese E., eds., 1984-1986, Fishes of the North-eastern Atlantic and the Mediterranean, UNESCO, vol. I (1984), 1-510, vol.II (1986), 511-1007, vol. III(1986), 1008-1473, Paris.

Yang J., Huang Z., Chen S. and Li Q. 1996. The Deep-Water Pelagic Fishes in the area from Nansha Islands to the Northeast part of South China Sea, Science Publication Company, Beijing. 190 pp.

Zachariasse W.J., Hinsbergen D.J.J. and Fortuin A.R. 2011. Formation and fragmentation of a late Miocene supradetachment basin in central Crete: implications for exhumation mechanisms of high-pressure rocks in the Aegean forearc, Basin Research, 23, 678-701. 